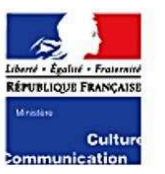

Secrétariat général

Délégation

au développement

et aux affaires

internationales

Département

des études,

de la prospective

et des statistiques

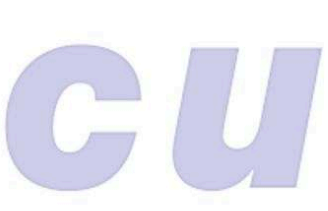

182, rue Saint-Honoré, 75033 Paris cedex 01

[ 0140157913 - 0140157999

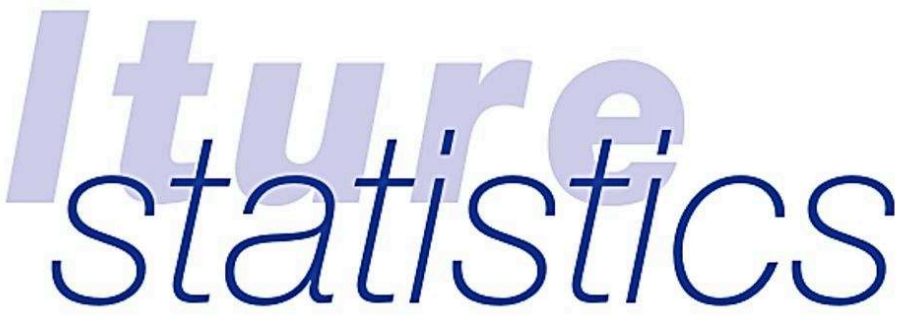

\title{
Employment in the cultural sector in 2005
}

\section{Éric Cléron, Frédérique Patureau*}

The annual National Institute for Statistics and Economic Studies (Institut national de la statistique et des études économiques, or INSEE ${ }^{1}$ ) Employment Survey, which is carried out each year by the Département des études, de la prospective et des statistiques (DEPS), allows the overall economic weight of jobs in the cultural sector ${ }^{2}$ to be measured, of which over half are now based in the cultural industries.

By analysing the results for 2005 , the broad characteristics of these jobs are revealed: in particular the heavy geographic weighting towards the Île-de-France and the considerable proportion of self-employed workers, along with the profile of those in these jobs, specifically their high-level of educational qualifications.

\section{0,000 PEOPLE WORKING WITHIN THE CULTURAL SECTOR}

In 2005 , around 460,000 people were employed in the culture sector, i.e. almost $2 \%$ of the active working population. For over half of these $(241,000$ or $52 \%$ : see Graph 1, p. 56), these jobs are concentrated in the cultural industries as follows: 87,000 in publishing and bookselling, 74,000 in the press, 40,000 in radio and television and 40,000 in cinema and video.

Live performance and artistic activities, which represent over a quarter of total culture sector jobs (28\%), account for the second-largest area of employment, with 133,000 jobs.

\section{Methodological limitations}

As there are relatively few workers in the cultural sector, random elements within the sample group may have a significant effect within the Employment Survey. This caveat should be borne in mind when considering the figures presented here. Nevertheless, the overall trends which emerged for 2005 confirm those which were observed the previous years*.

Moreover the terms "worker" or "workforce" here refer only to those in "active employment" excluding the unemployed.

In graphs etc., figures are rounded up, but the graphs accurately represent the initial data.

"See: http://www.culture.gouv.fr/deps publications statistiques (statistical information portal): Notes de l'Observatoire de l'emploi culturel, $\mathrm{n}^{\circ} 44$, mai 2006.

* Respectively INSEE's Statistical Officer and Research Engineer, both researchers in the Department for statistics, studies and strategic forsight (DEPS), joint heads of the "Trends in jobs, employment and labour" ("Dynamique des activités, de l'emploi et du travail") programme. They were assisted in their research and analysis by Anaiis Le Gouguec.

1. Carried out by INSEE, the Employment Survey provides data on the professions, the occupations of women or young people, work duration and casual work; it allows a more detailed picture of the situation of the unemployed and changes in working practices and patterns to emerge (see www.insee.fr).

2. See definition in the box on p. 60 . 


\section{Employment in the cultural sector in 2005}

L'emploi dans les professions culturelles en 2005

\section{Eric Cléron and Frédérique Patureau}

Publisher: Département des études, de la prospective et des statistiques

Place of publication: Paris

Year of publication: 2007

Published on OpenEdition Books: 21 September 2015

Serie: Culture chiffres

Electronic ISBN: 9782111398320

\section{Qboooks}

http://books.openedition.org

\section{Printed version}

Date of publication: 1 October 2007

Number of pages: 8

\section{Electronic reference}

CLÉRON, Eric ; PATUREAU, Frédérique. Employment in the cultural sector in 2005. New edition [online]. Paris: Département des études, de la prospective et des statistiques, 2007 (generated 25 avril 2021). Available on the Internet: <http://books.openedition.org/deps/801>. ISBN: 9782111398320.

(C) Département des études, de la prospective et des statistiques, 2007

Creative Commons - Attribution-NonCommercial 3.0 Unported - CC BY-NC 3.0 

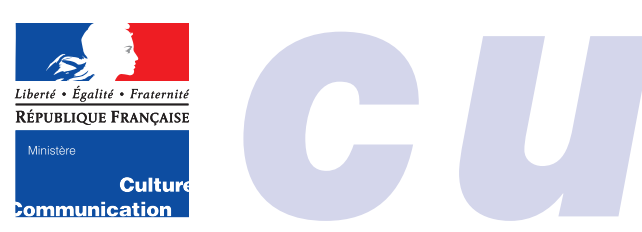

Secrétariat général

Délégation

au développement

et aux affaires

internationales

Département

des études,

de la prospective

et des statistiques

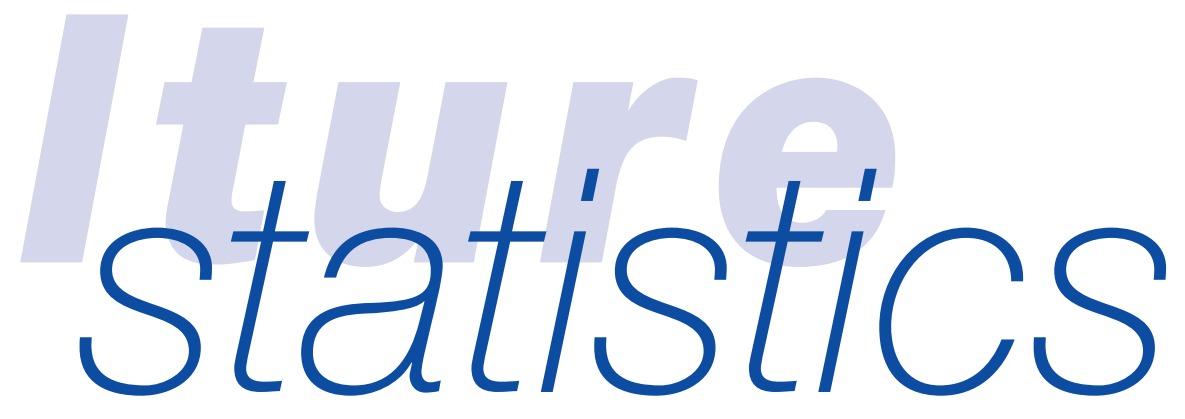

\title{
Employment in the cultural sector in 2005
}

\author{
Éric Cléron, Frédérique Patureau*
}

The annual National Institute for Statistics and Economic Studies (Institut national de la statistique et des études économiques, or INSEE ${ }^{1}$ ) Employment Survey, which is carried out each year by the Département des études, de la prospective et des statistiques (DEPS), allows the overall economic weight of jobs in the cultural sector ${ }^{2}$ to be measured, of which over half are now based in the cultural industries.

By analysing the results for 2005, the broad characteristics of these jobs are revealed: in particular the heavy geographic weighting towards the Île-de-France and the considerable proportion of self-employed workers, along with the profile of those in these jobs, specifically their high-level of educational qualifications.

\section{0,000 PEOPLE WORKING WITHIN THE CULTURAL SECTOR}

In 2005, around 460,000 people were employed in the culture sector, i.e. almost $2 \%$ of the active working population. For over half of these $(241,000$ or 52\%: see Graph 1, p. 56), these jobs are concentrated in the cultural industries as follows: 87,000 in publishing and bookselling, 74,000 in the press, 40,000 in radio and television and 40,000 in cinema and video.

Live performance and artistic activities, which represent over a quarter of total culture sector jobs $(28 \%)$, account for the second-largest area of employment, with 133,000 jobs.

\section{Methodological limitations}

As there are relatively few workers in the cultural sector, random elements within the sample group may have a significant effect within the Employment Survey. This caveat should be borne in mind when considering the figures presented here. Nevertheless, the overall trends which emerged for 2005 confirm those which were observed the previous years*.

Moreover the terms "worker" or "workforce" here refer only to those in "active employment" excluding the unemployed.

In graphs etc., figures are rounded up, but the graphs accurately represent the initial data.

*See: http://www.culture.gouv.fr/deps publications statistiques (statistical information portal): Notes de l'Observatoire de l'emploi culturel, n 44 , mai 2006.

\footnotetext{
* Respectively INSEE's Statistical Officer and Research Engineer, both researchers in the Department for statistics, studies and strategic forsight (DEPS), joint heads of the "Trends in jobs, employment and labour" ("Dynamique des activités, de l'emploi et du travail") programme. They were assisted in their research and analysis by Anaïs Le Gouguec.

1. Carried out by INSEE, the Employment Survey provides data on the professions, the occupations of women or young people, work duration and casual work; it allows a more detailed picture of the situation of the unemployed and changes in working practices and patterns to emerge (see www.insee.fr).

2. See definition in the box on p. 60 .
} 
1 - ... by occupational sector

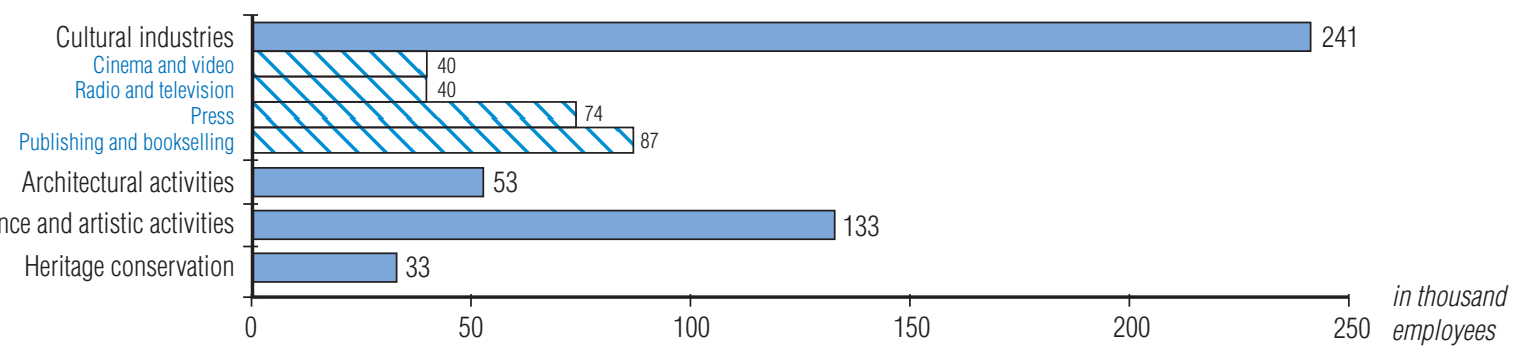

2 - ... by percentage of men per occupational sector

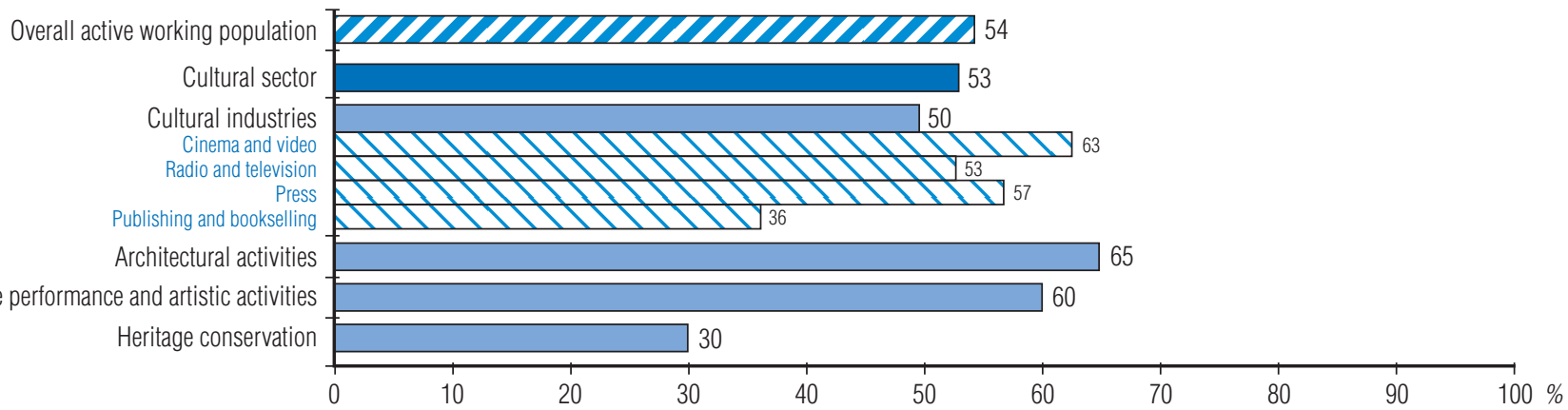

3 - ... by proportion of under-40s per occupational sector

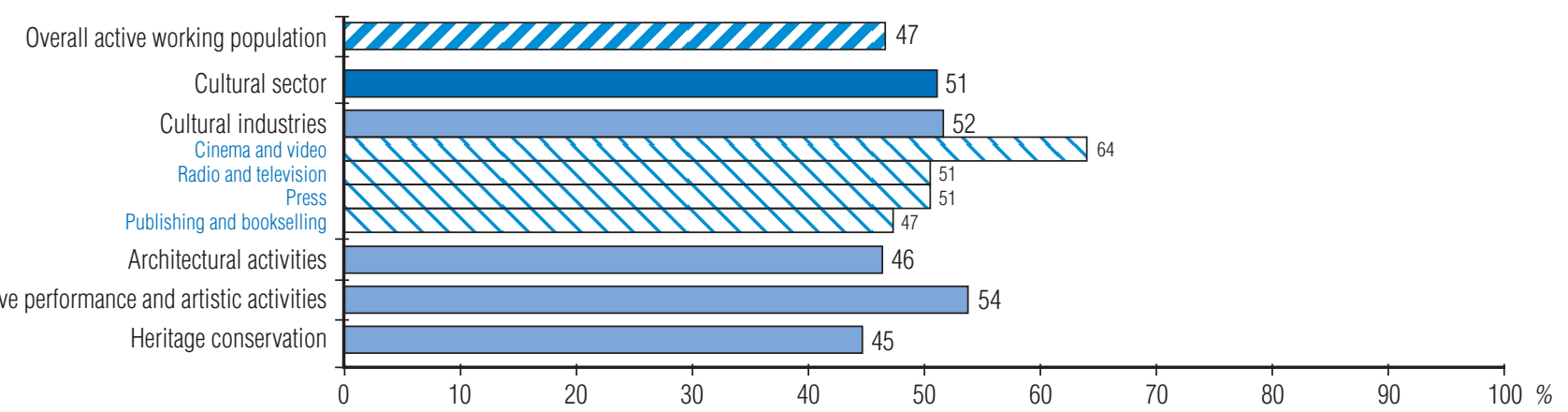

4 - ... by proportion of those with "baccalauréat" qualifications +2 or more additional years

of higher education per occupational sector

Overall active working population

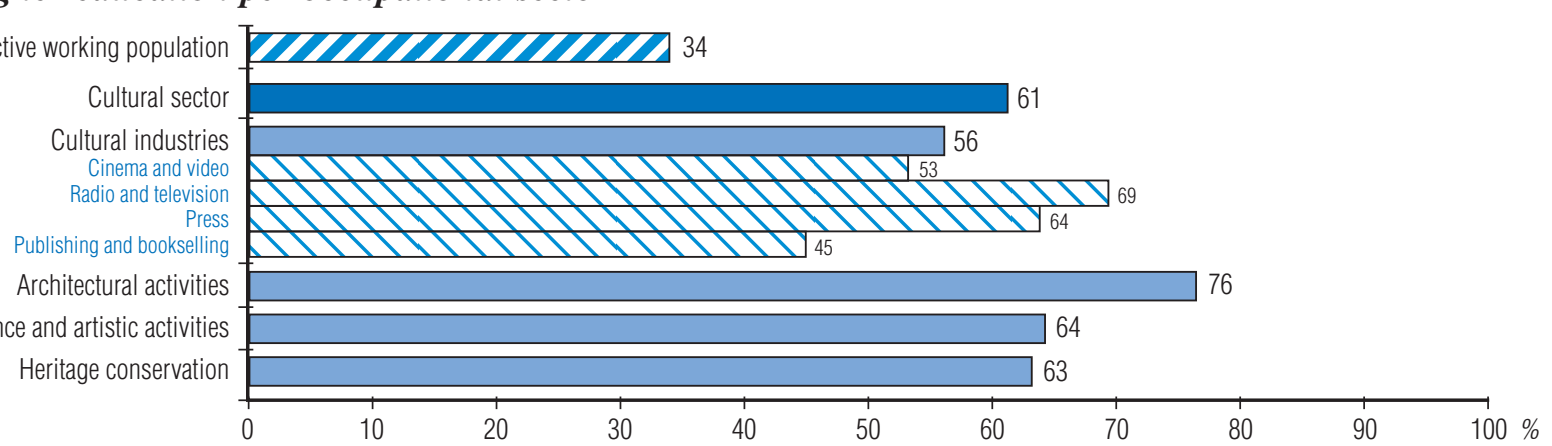

5 - ... by percentage of employees resident in the Île-de-France region per occupational sector

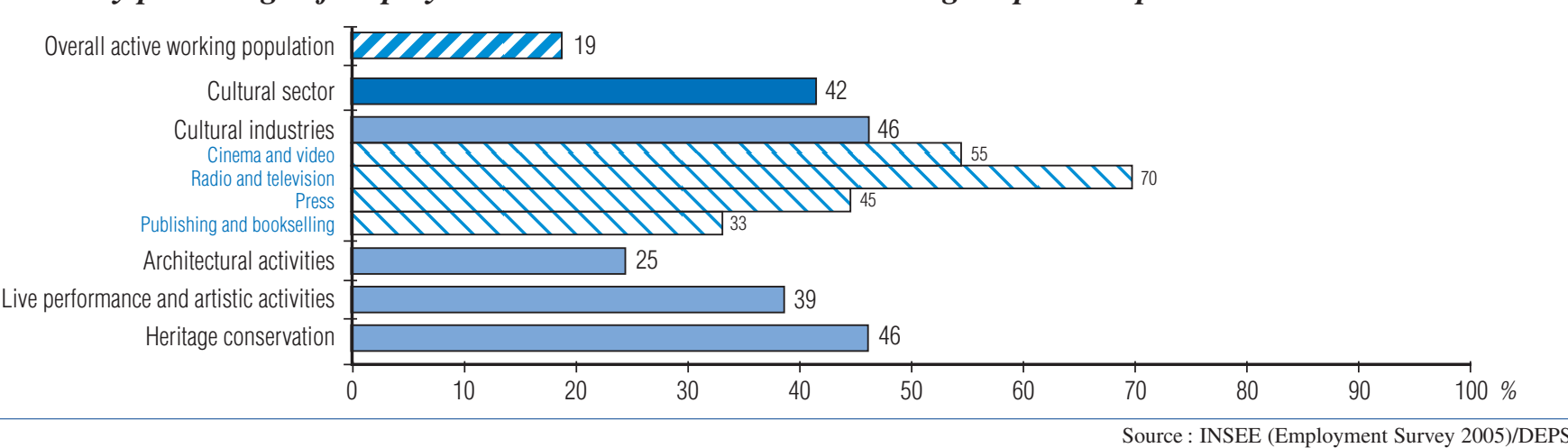


Architectural activities account for 53,000 jobs and those linked to heritage conservation 33,000 (respectively $12 \%$ and $8 \%$ of jobs in the sector).

\section{GENDER DISTRIBUTION SIMILAR TO THAT FOR OVERALL WORKING POPULATION}

Whilst the cultural sector is no different to other sectors of the economy in its slight overrepresentation of men (53\%, see Graph 2), this average does however cover considerable disparities, depending on the sector in question: thus, the proportion of men is particularly high in architectural activities $(65 \%)$, but much lower in the heritage conservation sector $(30 \%)$.

Within the cultural industries, gender distribution is far from homogeneous: higher in cinema and video $(63 \%)$, the proportion of men is much lower in publishing and bookselling, where conversely women are in the majority.

\section{OVER 50\% OF EMPLOYEES}

\section{ARE UNDER 40}

The distribution of employees shows a slight over-representation in the under-40s bracket within cultural activities (51\%, as opposed to $47 \%$ across the rest of the economy, see Graph 3). However, once again, this percentage varies markedly according to the occupational group: there are respectively $46 \%$ and $45 \%$ of under- 40 s in the architectural and heritage conservation sectors but $64 \%$ in cinema and video.

\section{A HIGHLY-QUALIFIED WORKFORCE}

Workers in the cultural sector are distinguished from the rest of the working population by their level of general education: indeed, almost two-thirds of them have attained educational qualifications equivalent to the baccalauréat +2 years of higher education, as compared with only one third for the rest of the working population (see Graph 4).

This high level of educational qualification is particularly prevalent in the area of architecture, (76\% of employees) and in radio and television $(69 \%)$.

\section{EMPLOYEES CONCENTRATED IN THE ILE-DE-FrANCE AND IN LARGE CITIES}

With $42 \%$ of its employees resident in the Îlede-France (see Graph 5), the cultural sector contrasts strongly with the rest of the working population (19\%). This is highest in the radio and television sector $(70 \%)$.

This strong geographical bias towards the Île-deFrance is redoubled and intensified, generally speaking, by a concentration of employees in urban areas: three-quarters of those working in the cultural sector live in municipalities which are part of urban centres (pôles urbains) ${ }^{3}$, whereas across all economic activities as a whole this figure is only 58\% (see Graph 6, p. 58). Concentration in urban centres is the highest of all in the radio and television sector $(92 \%)$.

\section{A HIGHER PROPORTION OF SELF-EMPLOYED WORKERS}

Within the cultural sector, almost one worker in four is self-employed, as compared with one in ten across the economy as a whole (see Graph 7, p. 58). This proportion of self-employed workers is particularly high for certain jobs: architecture (a sector in which there are numerous private practices), live performance, or even publishing and bookselling (particularly in the retail book, newspaper and stationary sector). In radio and television on the other hand, workers are almost all salaried and it is also very common within heritage conservation.

\section{LESS SECURE EMPLOYMENT}

Several indicators, such as the proportion of fixed-term contracts and part-time jobs, along with the prevailing underemployment situation, reveal that employment conditions within the cultural sector are less secure than for the rest of the economy.

Within the cultural sector, one in four salaried workers is employed on the basis of a fixed-term contract (26\%, as compared with $13 \%$ for all salaried workers, see Graph 8, p. 58).

In live performance, the proportion of such contracts is particularly high (over $50 \%$ of employees), and, to a lesser extent, in cinema, video, radio and television, which is explained by the nature of these

3. An urban centre (pôle urbain) is defined by INSEE as an urban area offering at least 5,000 jobs and which is not a commuter belt area surrounding another urban centre. 


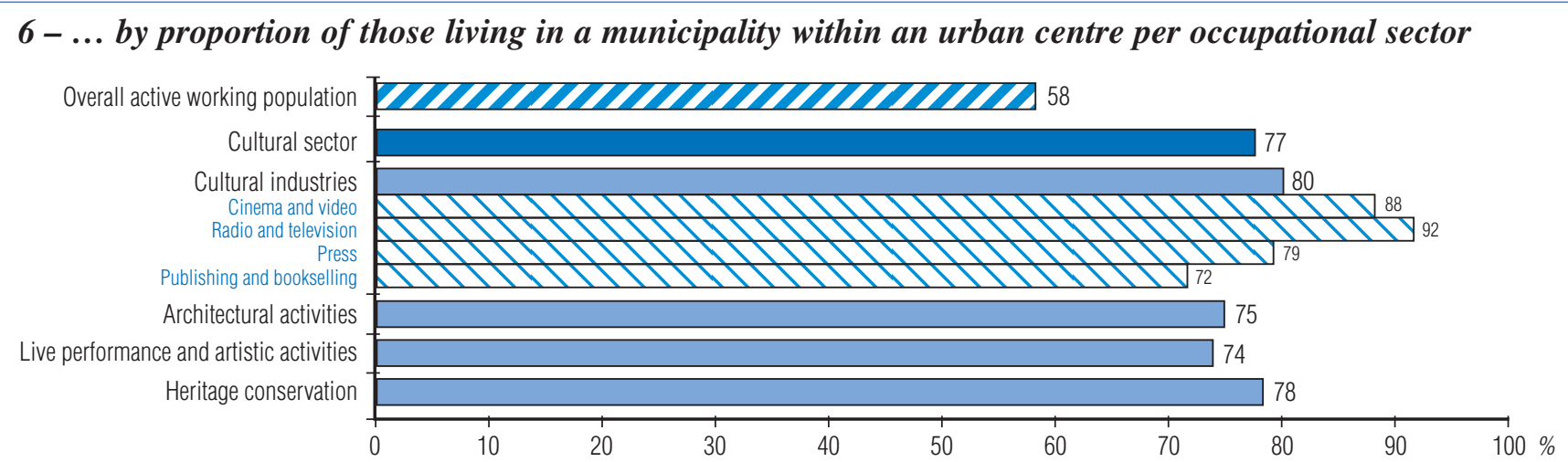

7 - ... by proportion of self-employed persons per occupational sector

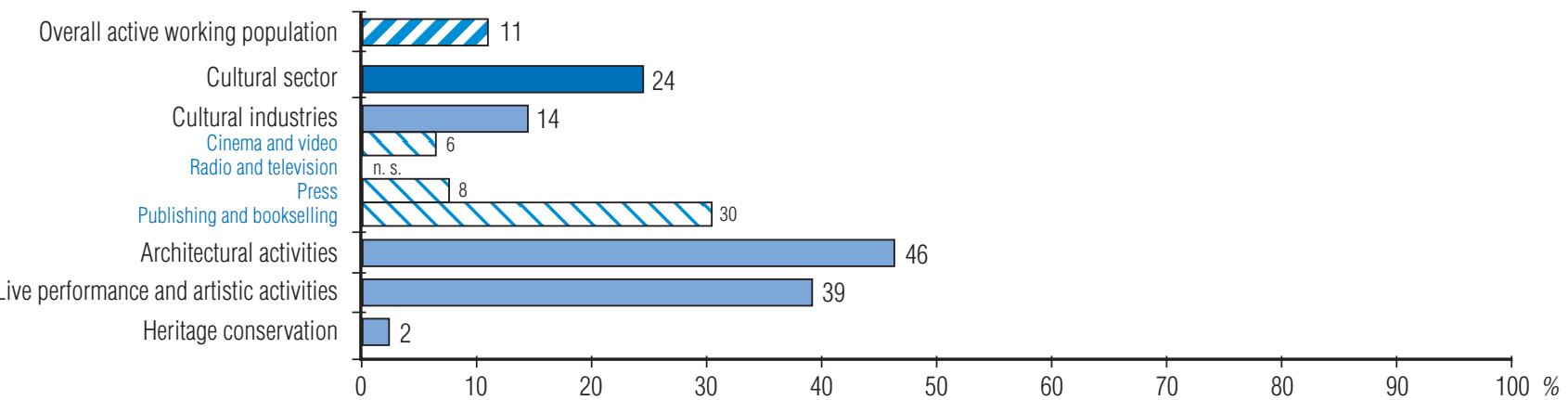

8 - ... by proportion of salaried workers on fixed-term contracts* per occupational sector

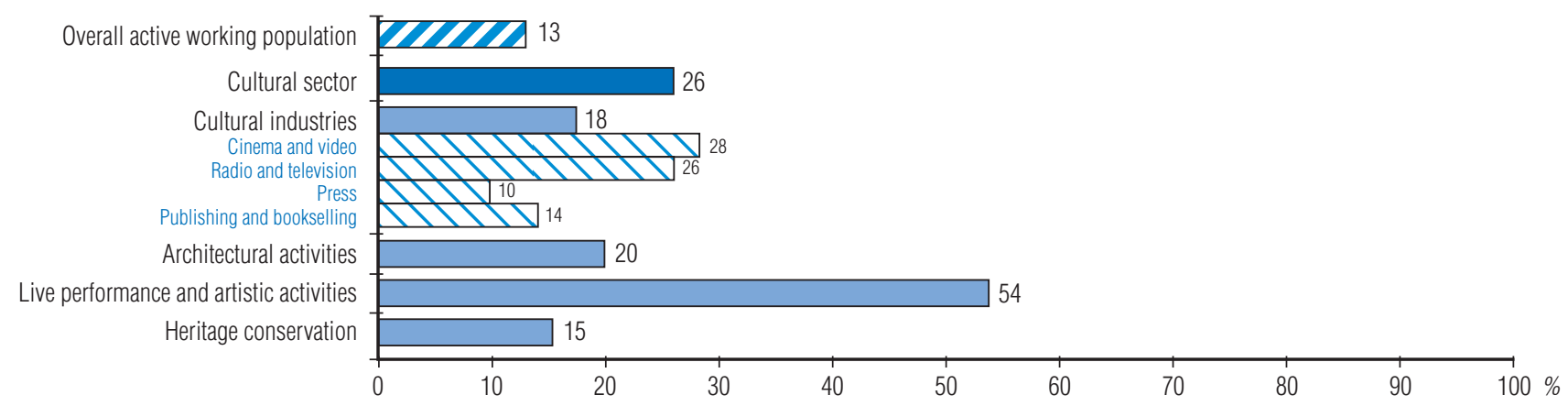

* Fixed-term contracts: any job on a fixed-term contract, government job creation scheme (Contrat emploi solidarité, CES), seasonal, intermittent contract, openended contract, supply teaching, etc.

\section{9 - ... by proportion of part-time workers per occupational sector}

Overall active working population Cultural sector Cultural industries Cinema and video Radio and television Press Architectural activities Live performance and artistic activities Heritage conservation
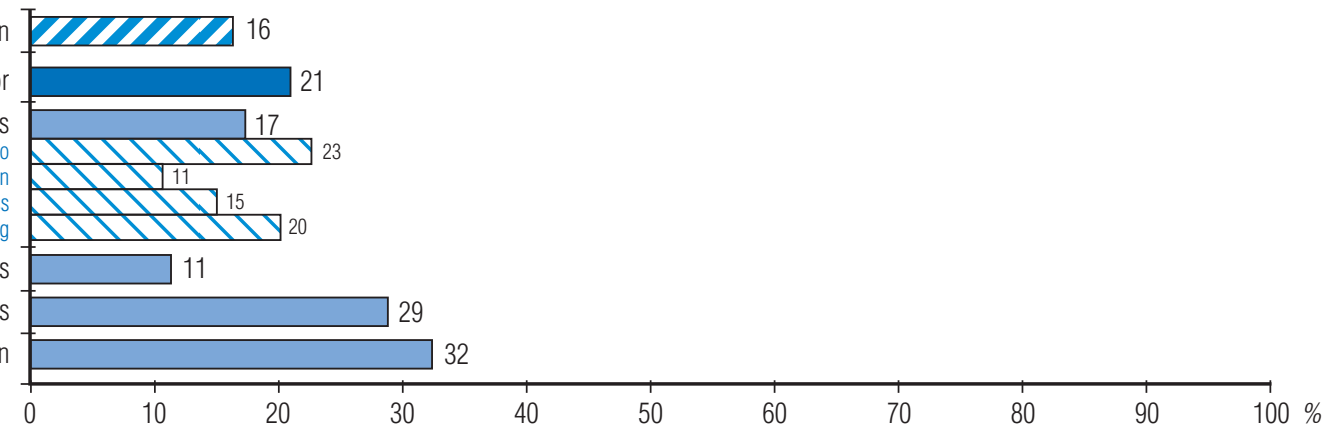

industries'intermittent working conditions (and thus the entertainment industry's so-called "standard" fixed-term contract).

Moreover, part-time work is slightly more frequent in the cultural sector than it is across the working population as a whole (respectively $21 \%$ and $16 \%$, see Graph 9). The proportion of part-time work is particularly high in heritage conservation $(32 \%)$ and in live performance (29\%), with a figure of only $11 \%$ for radio and television. 
10 - ... by proportion of "satisfied" workers per occupational sector

Overall active working population

Cultural sector

Cultural industries

Cinema and video

Radio and televisio

Publishing and bookselling

Architectural activities

Live performance and artistic activities

Heritage conservation
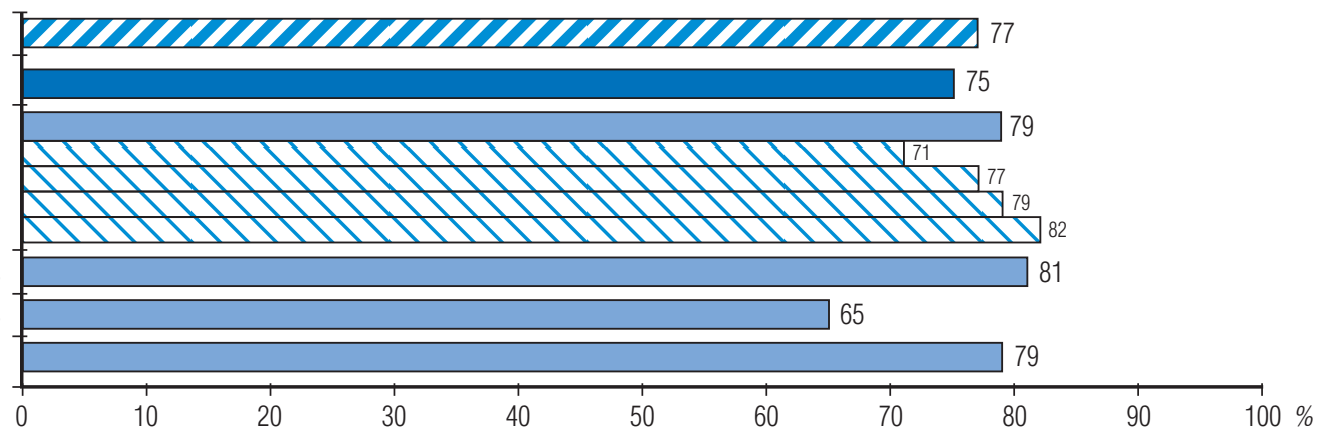

11 - ... by proportion of "underemployed" workers per occupational sector

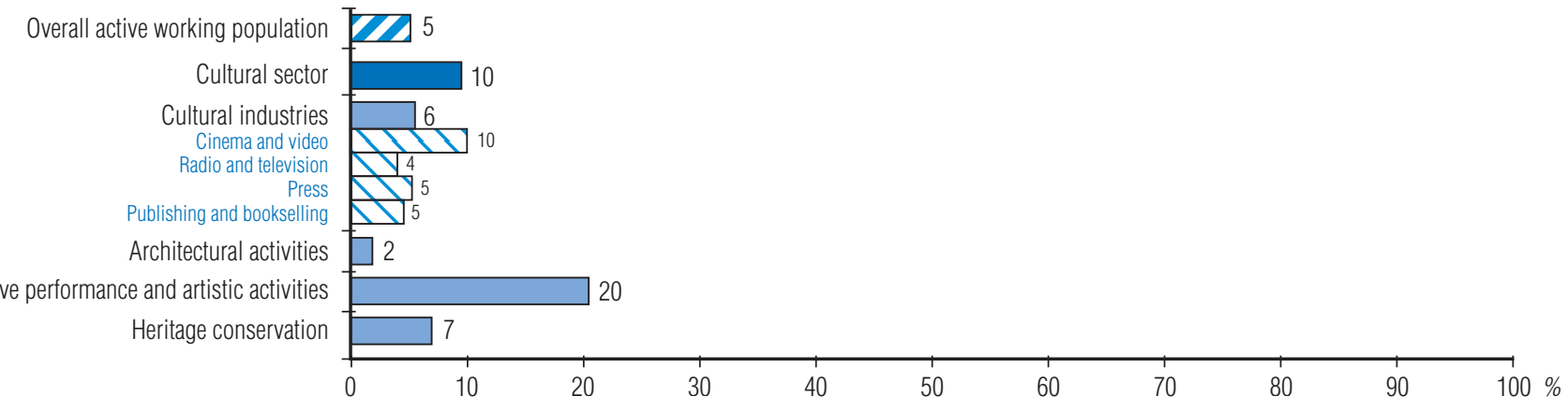

Source : INSEE (Employment Survey 2005)/DEPS

\section{UNEQUAL LEVELS OF "SATISFACTION"}

The degree of workers'job satisfaction ${ }^{4}$ within the cultural sector is practically identical to that across the working population as a whole (around $75 \%$, see Graph 10).

However, a significant proportion of "unsatisfied" workers is evident in the "live performance and artistic activities" field (35\%), and in "cinema and video" (29\%), whilst the percentage drops below $20 \%$ for those working in the fields of architecture and publishing and bookselling.

Such dissatisfaction levels may in some situations be explained by the higher levels of underemployment ${ }^{5}$ experienced in the cultural sector, particularly within the field of cinema and video, and especially within live performance and artistic activities (see Graph 11).

\footnotetext{
4. Within the scope of the Employment Survey, workers are declared "satisfied" if they do not fall within any of the following four categories: would like another job; would like to work fewer hours (with corresponding decrease in pay); would like to work more hours (with corresponding increase in pay); situation of underemployment.

5. Workers are classed as underemployed if they find themselves in one of the three following situations: in part-time work, seeking work which will give them more hours; part time, not seeking another job but wishing to work more and are available to do so; full-time but unwillingly working less than usual (short-time working, lay-off, etc.).
} 


\section{Cultural sector definition}

The data presented give a quantitative estimate and characterisation of jobs within the cultural sector, i.e. in all of the economic units whose principal activity, defined by reference to the French occupational classification system, are within the cultural sphere (see "Cultural sector" box, p. 61)

This by-sector approach, i.e. according to the nature of the business activity, allows us to build up a picture of cultural sector workers (in terms of age, sex, educational qualifications, etc), and the jobs which they do (nature of employment contract, employee/self employed, etc.) in whichever profession they may be.

Not all cultural sector workers, in fact, practice a cultural profession, i.e. a profession specific to the arts, performance and information sector: a good many of them do technical or administrative jobs, within cultural organisations, which exist in any other sector of the economy, Cinema and video businesses, for example, employ both cultural profession workers (actors, directors, sound engineers, etc.) as well as noncultural-sector professionals (secretaries, accountants, sales staff, etc.).

As is produced each year, an additional note, drawn up from the same Employment Survey, is added to this document, providing a description of workers and jobs in the cultural professions, in whichever occupational sector they are employed (see L'emploi dans les professions culturelles en 2005, Paris, DEPS, Ministère de la culture et de la communication, coll. «Culture chiffres » 2007-8).

http://www.culture.gouv.fr/deps publications statistiques (statistical information portal) 


\section{Cultural sector}

List of jobs defined under the French occupational nomenclature system (Nomenclature des activités française, NAF)

\section{CULTURAL INDUSTRIES}

\section{Publishing and bookselling}

22.1A Publishing of books (books, textbooks, pamphlets, atlases, maps and musical scores)

22.1G Publishing of sound recordings (records, compact discs and tapes containing music or other sound recordings)

22.1J Other publishing activities (calendars, postcards, art reproduction: art prints, photographs, images)

52.4R Retail sale of books, newspapers and stationery (and also office supplies and newsstand sales)

\section{Press}

22.1C Publishing of newspapers (daily newspapers, free papers)

22.1E Publishing of journals and periodicals

92.4Z Press agencies, freelance journalists

\section{Radio and television}

92.1A Production of motion pictures for television (all types of motion pictures: serials, television films, etc.)

92.2A Radio activities

92.2B Production of television programmes

92.2D Broadcast of general-interest television programmes

92.2E Broadcast of thematic television programmes

92.2F Distribution of television programme packages

\section{Motion picture and video activities}

92.1B Production of institutional and promotional motion pictures (advertising motion pictures, corporate technical motion pictures, training or educational motion pictures, video clips)

92.1C Production of motion pictures for cinema (short or featurelength destined to be shown in a motion picture projection room)

92.1D Technical services for cinema and television (sound recording, special effects, dubbing, etc.)

92.1F Motion pictures for cinema distribution (sale or rental of films or videos to other organisations)

92.1G Publishing and distribution of videos (sale or rental or motion pictures or videos for public release)

92.1J Motion picture projection

\section{ARCHITECTURE}

74.2A Architectural activities (architectural projects, technical consultancy, building project management, research and consultancy for land development and planning)

\section{LIVE PERFORMANCE AND ARTISTIC ACTIVITIES}

92.3A Artistic activities (self-employed artists: actors, musicians, dancers; permanent ensembles: orchestras, troupes, companies; performances; and other independent artists: painters, designers, sculptors, writers, etc.); cultural event organisation, promotion

92.3B Subsidiary services to entertainment (stage machinery, wardrobe, make-up, lighting)

92.3D Management of arts facilities (concert halls, theatres, cabaret, recording studios)

92.3K Various live entertainment activities (circuses, puppet shows, sound and light show, dance clubs, organisation of balls and evening events without the use of a specific venue)

\section{HERITAGE CONSERVATION}

92.5A Library management

92.5C Heritage conservation management (museums, sites, historic monuments)

\author{
Cultural professions \\ List of jobs defined under the French list \\ of occupational classifications \\ (professions et catégories socioprofessionnelles, PCS)
}

\section{AUDIOVISUAL OR LIVE PERFORMANCE OCCUPATIONS}

\section{Performers}

354b Musical artists and singers

354c Actors

354d Dancers, circus performers and other live performance artists

\section{Live performance managers, technicians and workers}

353b Directors and programme managers of audiovisual and live performances

353c Artistic and technical managers of audiovisual and live performances

465b Technical assistants for live performances and audiovisual events (salaried or self-employed)

637c Workers and technicians for live performances and audiovisual events

227a Independent live performance or recreational service managers

\section{OCCUPATIONS WITHIN THE VISUAL AND PLASTIC ARTS}

\section{Plastic Artists}

354a Visual artist

\section{Designers and decorators}

465a Designers and technical assistants in the graphic arts, fashion and interior design (self-employed or salaried)

\section{Photographers}

465c Photographers (salaried or self-employed)

\section{Arts and crafts professions}

214e Art artisans

637b Art workers

\section{LITERARY PROFESSIONS}

\section{Journalists and editorial managers}

352a Journalists and editors

353a Newspaper managers, press administrators, editors (literary, musical, audiovisual, multimedia)

\section{Literary writers}

352b Literary authors, scriptwriters, screenwriters

\section{DOCUMENTATION AND ARCHIVING MANAGERS AND TECHNICIANS}

351a State-employed librarians, archivists, senior librarians

$372 f$ Documentation managers, archive managers (privatelyfunded)

425a Documentation and archive technical assistants (privatelyfunded) (including assistant librarians and archivists)

ART TEACHERS (outside of educational institutions)

$354 \mathrm{~g}$ Art Teachers (outside of educational institutions)

\section{ARCHITECTS}

$312 f$ Independent architects

$382 \mathrm{~b}$ Salaried architects 